\title{
Perencanaan Sistem Instalasi Plambing Air Limbah dan Sistem Jaringan Perpipaan Air Limbah Infeksius di Gedung Unit Pelayanan Terpadu Geriatri dan Paliatif Rumah Sakit Cipto Mangunkusumo
}

\author{
AYU PRILLIYANI ${ }^{1}$, ANINDITO NURPRABOWO ${ }^{2}$, LINA APRIYANTI ${ }^{3}$ \\ 1,2,3 Jurusan Teknik Lingkungan, Fakultas Teknik Sipil dan Perencanaan, \\ ITENAS, Bandung.
}

Email: Ayuprilliyaniyuliadi@gmail.com

\begin{abstract}
ABSTRAK
Gedung unit pelayanan terpadu geriatri paliatif Rumah Sakit Cipto Mangunkusumo (RSCM) berfungsi sebagai unit perawatan untuk kondisi gangguan yang terjadi pada usia lanjut dan perawatan yang berkonsentrasi pada pengurangan keparahan gejala penyakit. Gedung perencanaan tersebut berada di kota Jakarta yang mengharuskan mematuhi Peraturan Gubernur DKI Jakarta Nomor 38 Tahun 2012 tentang Bangunan Gedung Hjau dengan aspek pengelolaan air limbah. Pengelolaan air limbah domestik dan air limbah infeksius bertujuan supaya tidak mecemari lingkungan sebelum air limbah tersebut dibuang ke badan air. Perencanaan sistem instalasi plambing air limbah perlu diketahui terlebih dahulu total kebutuhan air bersih dalam sehari untuk mengetahui debit air limbah dalam sehari, perencanaan jalur dan penentuan diameter pipa air limbah domestik dan limbah infeksius mengacu pada SNI-8153, 2015 dan SNI 03-7065, 2005. Hasil perhitungan, diperoleh debit air limbah domestik sebesar 142,99 $\mathrm{m}^{3} /$ hari dan debit air limbah infeksius sebesar 6,60 $\mathrm{m}^{3} /$ hari. Air limbah tersebut akan dialirkan ke instalasi pengolahan air limbah (IPAL) RSCM. Diameter pipa air limbah (domestik dan infeksius) berada pada rentang $50 \mathrm{~mm}$ sampai $150 \mathrm{~mm}$, dengan kemiringan pipa mendatar sebesar 10,4 $\mathrm{mm} / \mathrm{m}$. Jenis pipa yang digunakan yaitu pipa Poly Propylene Random (PPR) yang dapat digunakan untuk mengalirkan air limbah (domestik dan infeksius) serta bertahan pada aliran dengan keadaan asam dan basa kuat.
\end{abstract}

Kata kunci: Air limbah Domestik, Air Limbah infeksius, Sistem Plambing 


\begin{abstract}
The palliative geriatrics service building unit of Cipto Mangunkusumo Hospital (RSCM) serves as a treatment unit for disturbance conditions that occur in the elderly and treatment that concentrates on disease severity. Such activities produce domestic waste and airborne infectious waste. The planning building is located in the city of Jakarta which is leased Jakarta Governor Regulation no. 38 of 2012 on the building of buildings with the management of liquid waste. Management of domestic wastewater and infectious waste air no longer pollutes the environment before the exhaust is discharged into the rivers. Process of plumbing design, it is necessary to know in advance the total needs of water in a day to know the discharge of wastewater in a day, planning and determining the diameter of domestic wastewater pipe and waste infectious at SNI-8153, 2015 and SNI 03-7065, 2005. The calculation, obtained domestic wastewater discharge of $142.99 \mathrm{~m}^{3} /$ day and infectious waste water discharge of $6.60 \mathrm{~m}^{3} /$ day. The wastewater will be channeled to the RSCM wastewater treatment plant. The diameter of the wastewater (domestic and infectious) pipe is in the range $50 \mathrm{~mm}$ to $150 \mathrm{~mm}$, with a horizontal pipe slope of $10.4 \mathrm{~mm} / \mathrm{m}$. Poly Propylene Random (PPR), this type can be used to drain wastwater (domestic and infectious) and can withstand the flow with acidic and strong bases.
\end{abstract}

\title{
Keyword: Domestic Wastewater, Infectious Wastewater, Plumbing System
}

\section{PENDAHULUAN}

Gedung unit pelayanan terpadu geriatri dan paliatif Rumah Sakit Cipto Mangunkusumo berfungsi sebagai perawatan untuk kondisi gangguan yang terjadi pada usia lanjut dan perawatan yang berkonsentrasi pada pengurangan keparahan gejala penyakit. Kegiatan pelayanan tersebut menghasilkan limbah infeksius dan limbah domestik, baik dalam bentuk padat dan cair. Limbah infeksius terkategori limbah B3 berdasarkan Peraturan Pemerintah No. 101 Tahun 2014. Luas total penggunaan di gedung unit pelayanan terpadu geriatri dan paliatif RSCM sebesar $11.76 \mathrm{~m}^{2}$. Mengacu kepada Peraturan Gubernur Provinsi DKI Jakarta Nomor 38 Tahun 2012 tentang Bangunan Gedung Hijau dengan aspek pengelolaan a ir limbah, bangunan gedung hijau merupakan bangunan gedung yang bertanggung jawab terhadap lingkungan supaya tidak mencemari lingkungan sejak perencanaan. Oleh karena itu diperlukan pengelolaan air limbah (domestik dan infeksius) sebelum dibuang ke badan air.

Sistem plambing air limbah terdiri dari air bekas (grey water) dan air kotor (black water) yang berasal dari pemakaian air bersih, faktor timbulan air buangan sekitar $80 \%$ dari pemakaian air bersih (Hardjosuprapto, 2000). Sistem jaringan perpipaan air limbah infeksius yang terpisah dari air limbah domestik di perlukan untuk menjaga lingkungan hidup dari zat pencemar yang terkandung dalam air limbah infeksius pada gedung unit pelayanan terpadu geriatri dan paliatif RSCM.

Kegiatan yang menhasilkan limbah infeksius berasal dari kegiatan laboratorium dan ruang periksa pasien, sedangkan untuk kegiatan domestik contohnya berasal dari kegiatan yang ada di kamar inap, lobi dan dapur. 


\section{METODOLOGI}

Perencanaan sistem instalasi plambing air limbah dan sistem jaringan perpipaan air limbah infeksius di gedung unit pelayanan terpadu geriatri dan paliatif Rumah Sakit Cipto Mangunkusumo.

\subsection{Tahap Persiapan}

Tahap persiapan adalah tahap mengkaji literatur ilmiah mengenai teori-teori yang berhubungan dengan sistem plambing air limbah, dasar-dasar perencanaan sistem plambing dan standar yang digunakan, yaitu:

1. Regulasi

a. Peraturan Pemerintah Nomor 101 Tahun 2014 tentang Pengelolaan Limbah Berbahaya dan Beracun;

b. Peraturan Gubernur Provinsi Daerah Khusus IbuKota Jakarta Nomor 38 Tahun 2012 tentang Bangunan Gedung Hijau;

c. Peraturan Menteri Lingkungan Hidup dan Kehutanan Republik Indonesia Nomor 56 Tahun 2015 tentang Tata Cara dan Persyaratan Teknis Pengelolaan Limbah Bahan Berbaha dan Beracun dari Fasilitas Kesehatan

d. SNI - 8153:2015 tentang Sistem Plambing pada Bangunan Gedung;

2. Referensi/ Literatur Utama

a. Noerbambang, Soufyan M. dan Morimura, Taeko 2005. Perencanaan dan Pemeliharaan Sistem Plambing.

b. Hardjosuprapto, 2000. Penyaluran Air Buangan.

\subsection{Tahap Pengumpulan Data sekunder}

Data sekunder ini meliputi deskripsi dan gambar desain gedung (gambar arsitek), profil daerah perencanaan, fungsi dan luasan gedung per lantai serta diperoleh jumlah populasi gedung di setiap lantai.

\subsection{Tahap Pengolahan Data dan Perencanaan Teknis}

Pengolahan data dan perencanaan teknis untuk sistem instalasi plambing air limbah terdiri dari beberapa tahapan sebagai berikut:

a. Perhitungan debit air limbah (domestik dan infeksius)

Faktor timbulan air limbah yang digunakan sebesar 80\% (Hardjosuprapto, 2000) dari total kebutuhan air bersih untuk dapat melingkupi keseluruhan air limbah yang dihasilkan supaya tidak mencemari lingkungan sekitar.

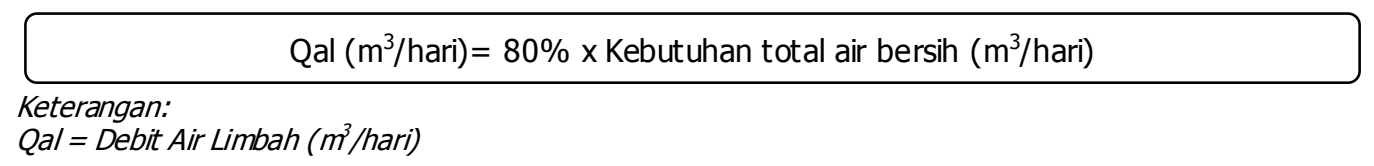

b. Perencanaan Teknis Air Limbah Domestik

- Detail Engineering Desain (DED) jalur dan dimensi pipa a ir limbah

Menentukan jalur pipa air limbah berdasarkan alat plambing yang digunakan pada gedung unit pelayanan terpadu geriatri dan paliatif RSCM, selanjutnya penentuan fixture unit (FU) unit beban alat plambing (UBAP) berdasarkan SNI8153, 2015 dan penentuan diameter pipa air limbah berdasarkan Perancangan dan Pemeliharaan Sistem Plambing (Noerbambang, 2005). 
- Detail Engineering Desain (DED) Jalur dan dimensi pipa ven

Menentukan jalur pipa ven dengan efektif dan efisien berdasarkan alat plambing yang digunakan pada gedung unit pelayanan terpadu geriatri dan paliatif RSCM, selanjutnya penentuan foxture unit (FU) unit beban alat plambing (UBAP) berdasarkan SNI-8153, 2015 dan penentuan diameter pipa ven berdasarkan Perancangan dan Pemeliharaan Sistem Plambing (Noerbambang, 2005).

\section{c. Perencanaan Teknis Air Limbah Infeksius}

- Detail Engineering Desain (DED) Jalur dan dimensi pipa a ir limbah infeksius

Menentukan jalur pipa air limbah infeksius berdasarkan alat plambing yang digunakan dan jenis limbah infeksius yang dihasilkan pada gedung unit pelayanan terpadu geriatri dan paliatif RSCM, selanjutnya penentuan fixture unit (FU) unit beban alat plambing (UBAP) berdasarkan SNI-8153, 2015 dan penentuan diameter pipa air limbah berdasarkan Perancangan dan Pemeliharaan Sistem Plambing (Noerbambang, 2005).

Tahapan perencanaan sistem instalasi plambing air limbah dan sistem jaringan perpipaan air limbah infeksius dapat dilihat pada Gambar 1.

Metode perencanaan dapat dilihat sebagai berikut:

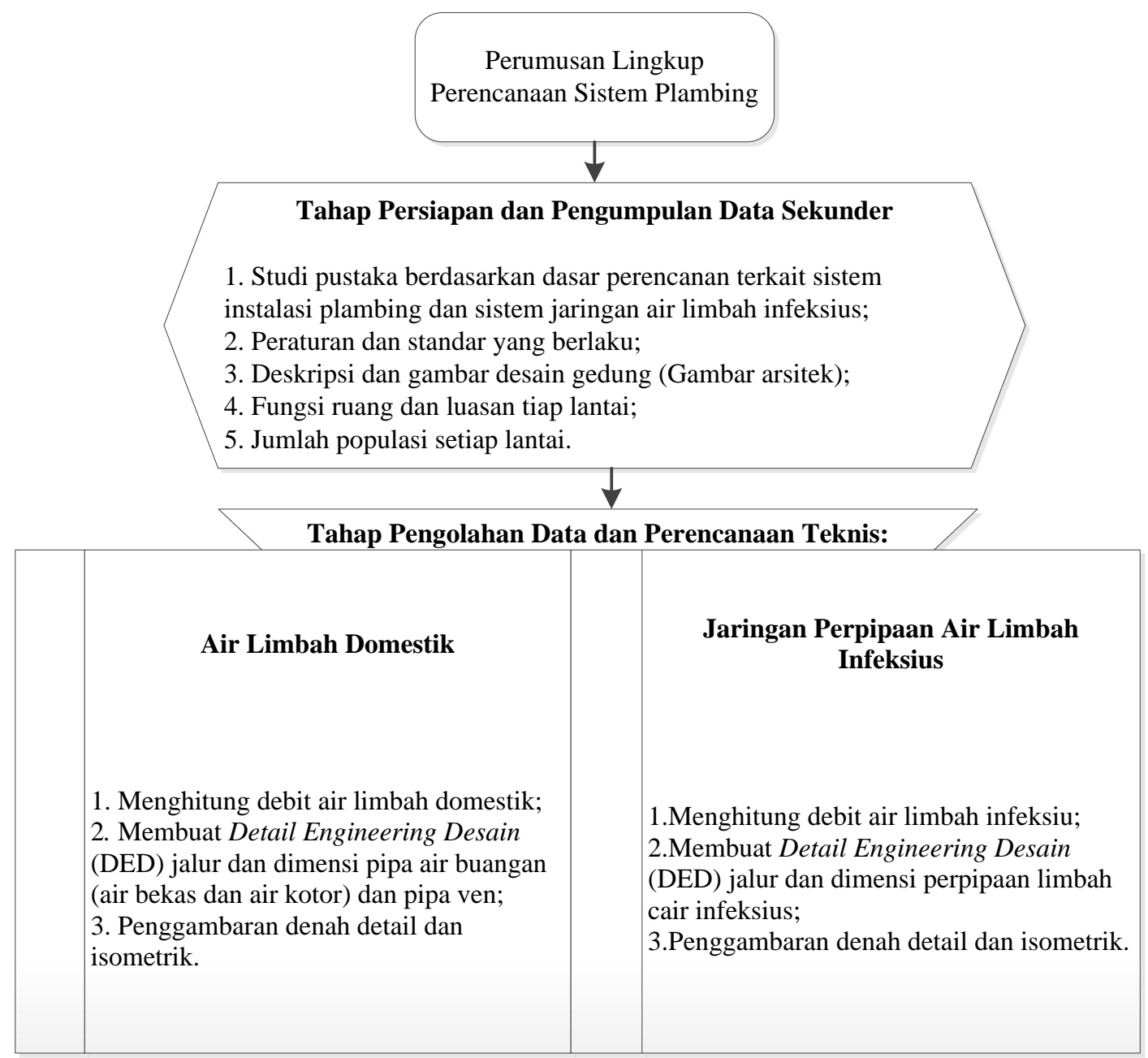

Gambar 1. Diagram Alir Tahapan Tugas Akhir 


\section{HASIL DAN PEMBAHASAN}

\subsection{Deskripsi Gedung}

Gedung unit pelayanan terpadu geriatri dan paliatif RSCM berfungsi sebagai ruang perawatan infeksius untuk kondisi gangguan yang terjadi pada usia tua dan ruang perawatan yang berkonsentrasi pada pengurangan keparahan gejala penyakit. Gedung unit pelayanan terpadu geriatri dan paliatif RSCM terdiri dari 13 lantai termasuk atap dan memiliki 820 unit alat plambing, dengan luas total penggunaan di gedung unit pelayanan terpadu geriatri dan paliatif RSCM sebesar $11.76 \mathrm{~m}^{2}$. Skematik air limbah domestik dan infeksius di gedung unit pelayanan terpadu geriatri dan paliatif RSCM dapat dilihat pada Gambar 2. Jalur air limbah domestik dan air limbah infeksius dilakukan secara terpisah supaya tidak mencemari lingkungan sebelum dibuang ke badan air.

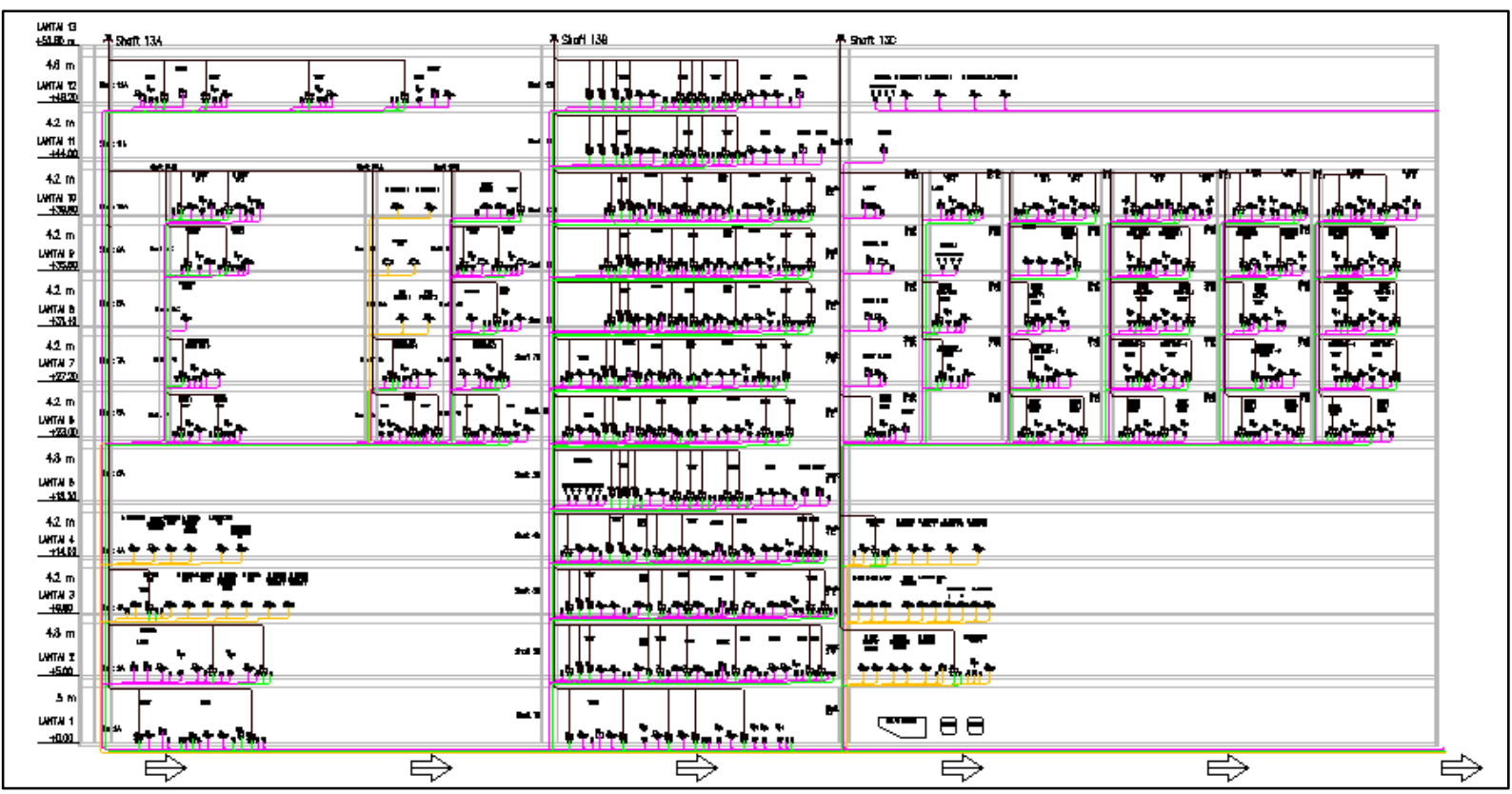

Gambar 2. Skematik Air Limbah Domestik dan Infeksius Sumber: Pengolahan Data, 2017

Keterangan:

1. Warna merah muda merupakan pipa air bekas (grey water) domestik;

2. Warna hijau merupakan pipa air kotor (blalck water);

3. Warna kuning merupakan pipa air bekas (grey water) air limbah infeksius (terdapat pada lantai 10,9,8,4 \& 3),

4. Warna hitam merupakan pipa ven.

\subsection{Debit Air Limbah}

Hasil perhitungan, kebutuhan total air bersih untuk kegiatan domestik sebesar 178,73 $\mathrm{m}^{3} /$ hari dan kebutuhan total air bersih untuk kegiatan infeksius sebesar $8,25 \mathrm{~m}^{3} /$ hari. Berikut merupakan contoh perhitungan untuk debit air limbah domestik.

$$
\begin{aligned}
\text { Qal }\left(\mathrm{m}^{3} / \text { hari }\right) & =80 \% \times 178,73 \mathrm{~m}^{3} / \text { hari } \\
& =142,99 \mathrm{~m}^{3} / \text { hari }
\end{aligned}
$$

Sumber: Pengolahan Data, 2017

Sehingga debit air limbah domestik dan infekisius sebagai berikut: 
Tabel 1. Rekapitulasi Debit Air Limbah

\begin{tabular}{lcc}
\hline & Domestik & Infeksius \\
\hline $\begin{array}{l}\text { Kebutuhan Total Air Bersih } \\
\left(\mathbf{m}^{3} / \text { hari) }\right.\end{array}$ & 178.73 & 8.25 \\
\hline Debit Air Limbah ( $\left.\mathbf{m}^{\mathbf{3}} / \mathbf{h a r i}\right)$ & 142.99 & 6.60 \\
\hline Sumber: Pengolahan Data, 2017 & &
\end{tabular}

Faktor timbulan air limbah yang digunakan dalam perencanaan ini sebesar $80 \%$ dari rentang 50\%-80\% (Harjosuprapto, 2000), dimana penggunakan rentang maksimum ini diharapkan semua air limbah yang dihasilkan dari penggunaan air bersih dapat disalurkan sehingga tidak mencemari lingkungan.

\subsection{Penentuan Diameter Pipa Mendatar Air Limbah Domestik}

Sistem pembuangan yang direncanakan di gedung unit pelayanan terpadu geriatri dan paliatif Rumah Sakit Cipto Mangunkusumo merupakan sistem buangan secara terpisah antara aliran air kotor (black water) dengan air berkas (grey water) dengan memanfaatkan sistem gravitasi (Noerbambang, 2005). Dipisahnya air limbah ini bertujuan untuk mengalirkan air limbah (air kotor, air bekas, ven) dari alat plambing menuju unit pengolahan. Dimana air limbah tersebut akan dialirkan ke instalasi pengolahan air limbah (IPAL) Rumah Sakit Cipto Mangunkusumo.

\subsubsection{Penentuan Diameter Pipa Mendatar Air Kotor (black water)}

Penentuan diameter pipa air kotor di gedung unit pelayanan terpadu geriatri dan paliatif Rumah Sakit Cipto Mangunkusumo terlebih dahulu dilakukan peninjauan satu per satu unit alat plambing yang terjauh dari setiap lantainya, setelah itu ditinjau fixture unit (FU) unit beban alat plambing (UBAP) sesuai dengan SNI-8153, 2015. Selanjutnya menghitung FU Kumulatif lalu menentukan diameter pipa berdasarkan Noerbambang, 2005. Untuk perhitungan diameter pipa air kotor (black water) dapat dilihat pada Tabel 2.

Ta bel 2. Contoh Perhitungan Diameter Pipa Air Kotor Lantai 1 Shaft $1 \mathrm{~A}$

\begin{tabular}{cccccc}
\hline \multicolumn{2}{c}{ Segmen } & \multirow{2}{*}{ Alat Plambing } & FU & FU & \multirow{2}{\emptyset}{} \\
\cline { 1 - 1 } Dari & Ke & & (UBAP) & Kum & $(\mathbf{m m})$ \\
\hline WC & A & Water Closet & 4 & 4 & 100 \\
\hline UR & A & Urinal & 2 & 2 & 50 \\
\hline A & B & - & - & 6 & 100 \\
\hline WC & B & Water Closet & 4 & 4 & 100 \\
\hline B & D & - & - & 10 & 100 \\
\hline WC & D & Water Closet & 4 & 4 & 100 \\
\hline D & Shaft 1A & - & - & 14 & 100 \\
\hline
\end{tabular}

Sumber: Pengolahan Data, 2017

Keterangan:

$\varnothing \quad=\operatorname{Diameter}(\mathrm{mm})$, berdasarkan Noerbambang, 2005;

FU UBAP = Fixture Unit Beban Alat Plambing, berdasarkan SNI- 8153, 2015;

FU Kum = Fixture Unit Kumulatif.

Berhasilkan hasil perhitungan, kebutuhan diameter pipa air kotor di gedung unit pelayanan terpadu geriatri dan paliatif RSCM yang terpilih pada perencanaan ini untuk lantai 1 shaft $1 \mathrm{~A}$ sebesar $50 \mathrm{~mm}$ sampai $100 \mathrm{~mm}$ dengan kemiringan pipa sebesar 10,4 mm/m. Jenis pipa yang digunakan yaitu pipa Poly Propylene Random (PPR). Gambar 3 menampilkan jalur pipa air kotor lantai 1 shaft $1 \mathrm{~A}$. 


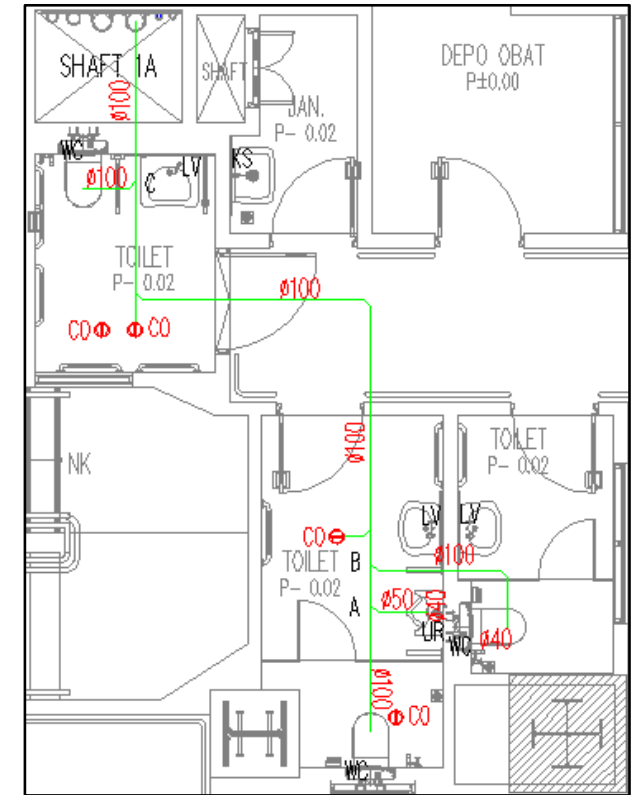

Gambar 3. Jalur Pipa Air Kotor Kegiatan Domestik Lantai 1 Shaft $1 \mathrm{~A}$ Sumber: Pengolahan Data, 2017 Keterangan:

Garis hijau merupakan jalur air kotor (black water)

\subsubsection{Penentuan Diameter Pipa Mendatar Air Bekas (grey water)}

Penentuan diameter pipa air bekas di gedung unit pelayanan terpadu geriatri dan paliatif Rumah Sakit Cipto Mangunkusumo terlebih dahulu dilakukan peninjauan satu per satu unit alat plambing yang terjauh dari setiap lantainya, setelah itu ditinjau fixture unit (FU) unit beban alat plambing (UBAP) sesuai dengan SNI-8153, 2015. Selanjutnya menghitung FU Kumulatif lalu menentukan diameter pipa yang dibutuhkan berdasarkan Noerbambang, 2005. Untuk perhitungan diameter pipa air bekas (grey water) dapat dilihat pada Tabel 3.

Tabel 3. Contoh Perhitungan Diameter Pipa Air Bekas Lantai 1 Shaft $1 \mathrm{~A}$

\begin{tabular}{|c|c|c|c|c|c|}
\hline \multicolumn{2}{|c|}{ Segmen } & \multirow{2}{*}{ Alat Plambing } & \multirow{2}{*}{$\begin{array}{c}\text { FU } \\
\text { (UBAP) }\end{array}$} & \multirow{2}{*}{$\begin{array}{c}\text { FU } \\
\text { Kum }\end{array}$} & \multirow{2}{*}{$\begin{array}{c}\varnothing \\
(\mathrm{mm})\end{array}$} \\
\hline Dari & Ke & & & & \\
\hline FD & $A$ & Floor Drain & 2 & 2 & 50 \\
\hline LV & $B$ & Lavatory & 1 & 1 & 50 \\
\hline $\mathrm{B}$ & D & - & - & 3 & 50 \\
\hline FD & C & Floor Drain & 2 & 2 & 50 \\
\hline LV & $\mathrm{C}$ & Lavatory & 1 & 1 & 50 \\
\hline $\mathrm{C}$ & D & - & - & 3 & 50 \\
\hline $\mathrm{D}$ & $\mathrm{F}$ & - & - & 6 & 50 \\
\hline KS & $E$ & Kitchen Sink & 2 & 2 & 50 \\
\hline FD & $E$ & Floor Drain & 2 & 2 & 50 \\
\hline LV & $\mathrm{E}$ & Lavatory & 1 & 1 & 50 \\
\hline$E$ & $\mathrm{~F}$ & - & - & 5 & 50 \\
\hline $\mathrm{F}$ & Shaft 1A & - & - & 11 & 80 \\
\hline
\end{tabular}

Sumber: Pengolahan Data, 2017

Keterangan:

$\varnothing \quad=$ Diameter $(\mathrm{mm})$, berdasarkan Noerbambang, 2005;

FU UBAP = Fixture Unit Beban Alat Plambing, berdasarkan SNI- 8153, 2015;

FU Kum = Fixture Unit Kumulatif.

Berdasarkan hasil perhitungan, kebutuhan diameter pipa air bekas di gedung unit pelayanan terpadu geriatri dan paliatif RSCM yang terpilih pada perencanaan ini untuk lantai 1 shaft $1 \mathrm{~A}$ sebesar $50 \mathrm{~mm}$ sampai $80 \mathrm{~mm}$ dengan kemiringan pipa sebesar $10,4 \mathrm{~mm} / \mathrm{m}$. Jenis pipa yang digunakan yaitu pipa Poly Propylene Random (PPR). Gambar 4 menampilkan jalur pipa air bekas lantai 1 shaft $1 \mathrm{~A}$. 


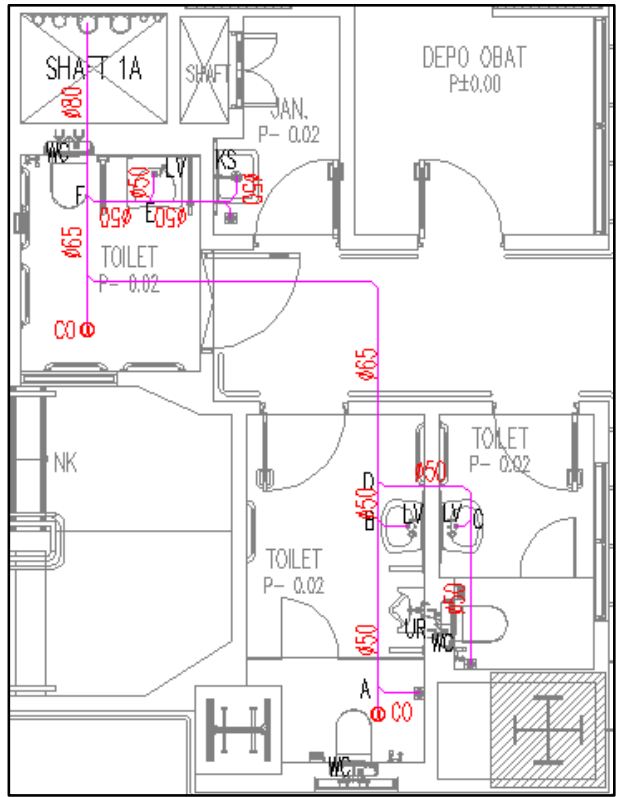

Gambar 4. Jalur Pipa Air Bekas Kegiatan Domestik Lantai 1 Shaft $1 \mathrm{~A}$ Sumber: Pengolahan Data, 2017 Keteramgan:

Garis merah muda merupakan jalur air bekas (grey water)

\subsubsection{Penentuan Diameter Pipa Mendatar Ven}

Pipa ven dipasang untuk dapat mensirkulasikan udara ke seluruh bagian dari sistem pembuangan dan mencegah terjadinya kerja sifon dan tekanan balik pada perangkap. Sistem pipa ven yang digunakan yaitu sistem tunggal, dimana pipa ven tunggal ini dipasang pada setiap alat plambing dan disambungkan ke pipa ven cabang mendatar lainnya dan disambungkan pada pipa tegak ven (Noerbambang, 2005).

Penentuan diameter pipa ven di gedung unit pelayanan terpadu geriatri dan paliatif Rumah Sakit Cipto Mangunkusumo terlebih dahulu dilakukan peninjauan satu per satu unit alat plambing yang terjauh dari setiap lantainya, setelah itu ditinjau fixture unit (FU) unit beban alat plambing (UBAP) sesuai dengan SNI 8153, 2015. Selanjutnya menghitung FU Kumulatif lalu menentukan diameter pipa yang dibutuhkan berdasarkan Noerbambang, 2005. Untuk perhitungan diameter pipa ven dapat dilihat pada Tabel 4.

Tabel 4. Contoh Perhitungan Diameter Pipa Ven Lantai 1 Shaft $1 \mathrm{~A}$

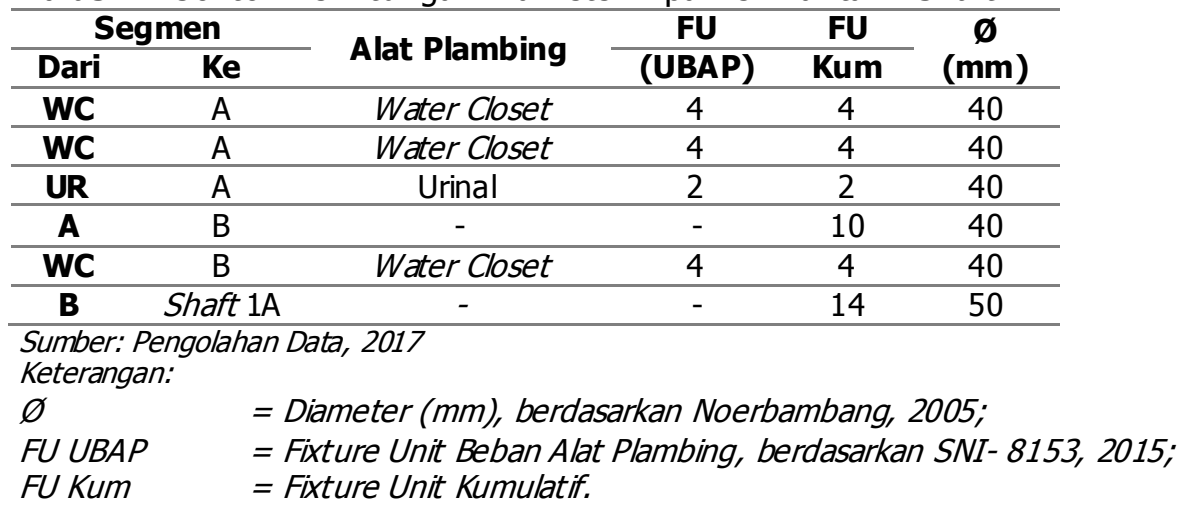

Berdasarkan hasil perhitungan, kebutuhan diameter pipa ven di gedung unit pelayanan terpadu geriatri dan paliatif Rumah Sakit Cipto Mangunkusumo yang terpilih pada perencanaan ini untuk lantai 1 shaft $1 \mathrm{~A}$ sebesar $40 \mathrm{~mm}$ sampai $50 \mathrm{~mm}$ dengan kemiringan 
pipa sebesar $10,4 \mathrm{~mm} / \mathrm{m}$. Jenis pipa yang digunakan yaitu pipa Poly Propylene Random (PPR). Gambar 5 menampilkan jalur pipa ven lantai 1 shaft 1A.

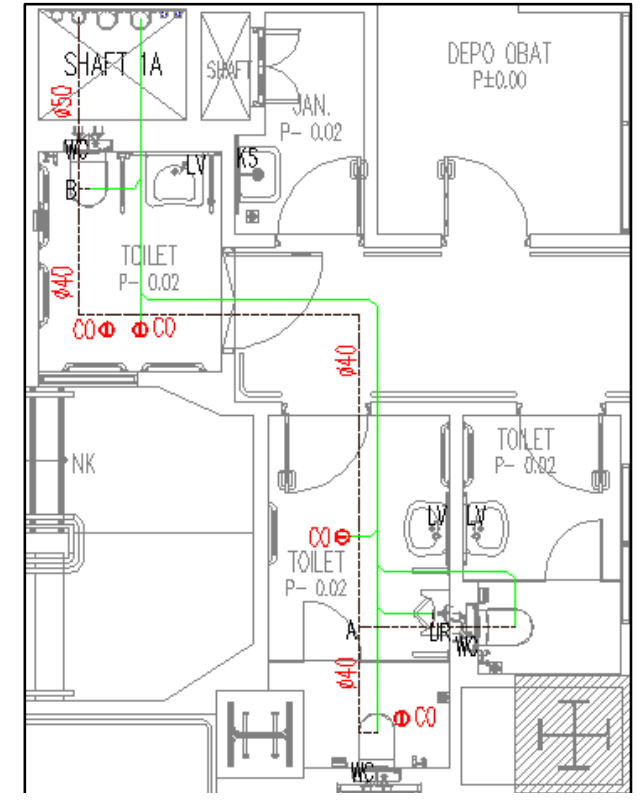

Gambar 5. Jalur Pipa Ven Lantai 1 Shaft $1 \mathrm{~A}$

Sumber: Pengolahan Data, 2017 Keterangan:

Garis hitam merupakan jalur ven

Garis hujau merupakan jalur air kotor (black water)

\subsection{Penentuan Pipa Mendatar Air Bekas (grey water) Air limbah Infeksius}

Mengacu pada Peraturan Gubernur DKI Jakarta Nomor 38 Tahun 2012 gedung pelayanan terpadu geriatri dan paliatif RSCM melakukan pengelolaan air limbah yang bertujuan supaya hasil buangan air limbah infeksius tersebut tidak langsung dibuang ke badan air. Gedung perencanan ini melewati sistem jaringan perpipaan air limbah yang di miliki oleh RSCM maka wajib memanfaatkan jaringan air limbah yang akan di alirkan ke IPAL RSCM.

Penentuan diameter pipa air bekas di gedung unit pelayanan terpadu geriatri dan paliatif Rumah Sakit Cipto Mangunkusumo terlebih dahulu dilakukan peninjauan satu per satu unit alat plambing yang terjauh dari setiap lantainya, setelah itu ditinjau fixture unit (FU) unit beban alat plambing (UBAP) sesuai dengan SNI-8153:2015. Selanjutnya menghitung FU Kumulatif lalu menentukan diameter pipa yang dibutuhkan berdasarkan Noerbambang, 2005. Untuk perhitungan diameter pipa air bekas ( grey water) dapat dilihat pada Tabel 5.

Ta bel 5. Contoh Perhitungan Diameter Pipa Air Bekas Air limbah Infeksius Lantai 3 Shaft $3 \mathrm{~A}$

\begin{tabular}{|c|c|c|c|c|c|}
\hline \multicolumn{2}{|c|}{ Segmen } & \multirow{2}{*}{ Alat Plambing } & \multirow{2}{*}{$\begin{array}{c}\text { FU } \\
\text { (UBAP) }\end{array}$} & \multirow{2}{*}{$\begin{array}{c}\text { FU } \\
\text { Kum }\end{array}$} & \multirow{2}{*}{$\begin{array}{c}\varnothing \\
(\mathbf{m m})\end{array}$} \\
\hline Dari & Ke & & & & \\
\hline LV & $A$ & Lavatory & 1 & 1 & 50 \\
\hline FD & A & Floor Drain & 2 & 2 & 50 \\
\hline A & B & - & - & 3 & 50 \\
\hline LV & B & Lavatory & 1 & 1 & 50 \\
\hline$B$ & C & - & - & 4 & 50 \\
\hline \multicolumn{2}{|c|}{ Poin C } & - & - & 4 & 50 \\
\hline C & Shaft 3A & - & - & 8 & 65 \\
\hline
\end{tabular}

Sumber: Pengolahan Data, 2017

Keterangan:

$\varnothing \quad=\operatorname{Diameter}(\mathrm{mm})$, berdasarkan Noerbambang, 2005;

FU UBAP = Fixture Unit Beban Alat Plambing, berdasarkan SNI- 8153, 2015;

FU Kum = Fixture Unit Kumulatif. 
Dari hasil perhitungan, kebutuhan diameter pipa air bekas air limbah infeksius di gedung unit pelayanan terpadu geriatri dan paliatif RSCM yang terpilih pada perencanaan ini untuk lantai 3 shaft 3A sebesar $50 \mathrm{~mm}$ sampai $65 \mathrm{~mm}$ dengan kemiringan pipa sebesar 10,4 mm/m. Jenis pipa yang digunakan yaitu pipa Poly Propylene Random (PPR). Gambar 6 menampilkan jalur pipa air bekas air limbah infeksius.

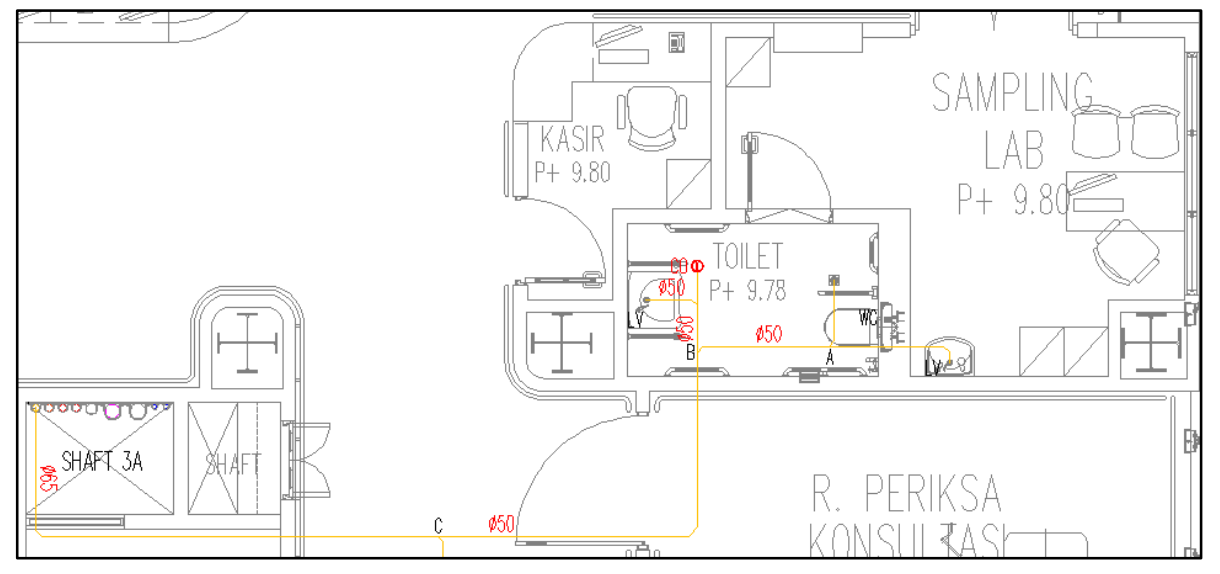

Gambar 6. Jalur Pipa Air Bekas Air limbah Infeksius Lantai 3 Shaft 3A Sumber: Pengolahan Data, 2017 Keterangan:

Garis kuning merupakan jalur air bekas (grey water) infeksius

\section{KESIMPULAN}

Debit a ir limbah domestik yang dihasilkan sebesar 142,99 $\mathrm{m}^{3} /$ hari dan untuk debit a ir limbah infeksius sebesar $6,6 \mathrm{~m}^{3} /$ hari. Diameter pipa mendatar air limbah di gedung unit pelayanan terpadu geriatri dan paliatif Rumah Sakit Cipto Mangunkusumo untuk air kotor memiliki rentang $100 \mathrm{~mm}$ sampai $150 \mathrm{~mm}$, air bekas $50 \mathrm{~mm}$ sampai $150 \mathrm{~mm}$ dan untuk ven $40 \mathrm{~mm}$ sampai $125 \mathrm{~mm}$. Kemiringan pipa mendatar sebesar $10,4 \mathrm{~mm} / \mathrm{m}$. Jenis pipa yang digunakan yaitu pipa Poly Propylene Random (PPR), dimana jenis pipa ini dapat digunakan untuk mengalirkan air limbah (domestik dan infeksius) dan dapat bertahan pada aliran asam dan basa kuat.

\section{DAFTAR PUSTAKA}

Hardjosuprapto, M. (2000). Penyaluran Air Buangan Volume I: ITB: Bandung.

Noerbambang, S. M. (2005). Perancangan Dan Pemeliharaan Sistem Plambing (6 ed.). Jakarta: PT Pradnya Patamita.

Peraturan Gubernur Provinsi DKI Kota Jakarta No. 38 Tahun 2012 tentang Bangunan Gedung Hijau.

Peraturan Menteri Lingkungan Hidup dan Kehutanan Republik Indonesia Nomor 56 Tahun 2015 tentang Tata Cara dan Persyaratan Teknis Pengelolaan Limbah bahan Berbahaya dan Beracun dari Fasilitas Prlanan Kesehatan.

Peraturan Pemerintah Republik Indonesia Nomor 101 Tahun 2014 tentang Pengelolaan Limbah Berbahaya dan Beracun.

SNI-8153, S. N. I. (2015) Sistem Plambing pada Bangunan Gedung. 